University of Nebraska - Lincoln

DigitalCommons@University of Nebraska - Lincoln

1977

\title{
A New Host for Pleistophora ovariae (Microsporida)
}

Glenn L. Hoffman

US Fish and Wildlife Service

Mary L. Nagel

Oklahoma State University

Follow this and additional works at: https://digitalcommons.unl.edu/usfwspubs

Part of the Aquaculture and Fisheries Commons

Hoffman, Glenn L. and Nagel, Mary L., "A New Host for Pleistophora ovariae (Microsporida)" (1977). US Fish \& Wildlife Publications. 113.

https://digitalcommons.unl.edu/usfwspubs/113

This Article is brought to you for free and open access by the US Fish \& Wildlife Service at DigitalCommons@University of Nebraska - Lincoln. It has been accepted for inclusion in US Fish \& Wildlife Publications by an authorized administrator of DigitalCommons@University of Nebraska - Lincoln. 


\section{A New Host for Pleistophora ovariae (Microsporida)}

Pleistophora ovariae, a microsporidan para- shiners held at 45 of 49 commercial fish farms site that infects ovaries of the golden shiner inspected by Summerfelt and Warner (1970, J (Notemigonus crysoleucas), is a widespread Wildl Dis 6: 457-465). This microsporidan problem for minnow culturists. It occurred in causes considerable damage to golden shiner 
TABLE I. Characteristics of Pleistophora species occurring in fish gonads.

\begin{tabular}{|c|c|c|c|c|}
\hline \multirow[b]{2}{*}{ Species } & \multicolumn{2}{|c|}{ Spore morphology } & \multirow[b]{2}{*}{ Host } & \multirow[b]{2}{*}{ Site } \\
\hline & Shape & Size in $\mu \mathrm{m}$ & & \\
\hline P. mirandellae (1901) & ovoidal & $\begin{array}{l}12 \times 6 \text { and } \\
7.5 \times 4\end{array}$ & Alburnus mirandella & France \\
\hline P. elegans (1910) & highly elongate & $10 \times 4$ & $\begin{array}{l}\text { Abramis brama } \times \\
\text { Leuciscus rutilus }\end{array}$ & Germany \\
\hline P. sciaenae (1919) & pyriform & $3-5 \times 2-3$ & Sciana australis & Australia \\
\hline P. oolytica (1948) & pyriform & $\begin{array}{l}8.4 \times 4.2, \\
5.5-6.5 \times 3.5, \\
\text { and } 3.0 \times 1.5\end{array}$ & $\begin{array}{l}\text { Esox lucius } \\
\text { Leuciscus cephalus }\end{array}$ & Prague \\
\hline P. ovariae (1964) & pyriform & $\begin{array}{l}8.42 \times 4.24 \\
(\text { fresh), } 6.60 \times \\
3.31 \text { (fixed), } \\
8.20-6.80 \times \\
4.00-4.80\end{array}$ & Notemigonus crysoleucas & United States \\
\hline P. ovariae (this paper) & pyriform & $7.43 \times 4.35$ & Pimephales promelas & United States \\
\hline
\end{tabular}

Information for this table was taken from the following sources: Kudo, 1924, Ill Biol Monogr 9: 268 pp.; Summerfelt, 1964, Trans Am Fish Soc 93: 6-10; Summerfelt and Warner, 1970, Am Fish Soc Spec Publ No 5: 142-160; Weiser, 1948, Parasitology 39: 164-166.

ovaries, reducing fecundity, but most fish farmers obtain an adequate supply of eggs from young fish ( 1 or 2 years old) in which ovarian damage is not yet extensive.

In a sample of fathead minnows (Pimephales promelas) from Arkansas examined for routine disease diagnosis in March 1976, one minnow was found with a microsporidan infection of the ovary. Although fathead minnows are often raised at the same farms as golden shiners, $P$. ovariae has not previously been reported from them. Both ovaries of the infected fathead minnow were preserved in $10 \%$ formalin for parasite identification. A random sample of 50 spores was measured at a magnification of $675 \times$ with an ocular micrometer calibrated against a stage micrometer. Histological sections of the remaining ovary material were prepared for observation of the infection pattern.

The spores from the fathead minnow were pyriform, like those of most species of Pleistophora occurring in fish gonads. The average length of 50 preserved spores was $7.43 \pm 0.89$ $\mu \mathrm{m}$ and the average width, $4.34 \pm 0.40 \mu \mathrm{m}$. These values fall close to those given in the original description of $P$. ovariae in Illinois: $8.42 \pm 0.17 \mu \mathrm{m}$ by $4.24 \pm 0.15 \mu \mathrm{m}$ for fresh spores and $6.44 \pm 0.11 \mu \mathrm{m}$ by $3.43 \pm 0.05 \mu \mathrm{m}$ for Schaudinn-fixed spores, and $6.60 \pm 0.08$ by $3.31 \pm 0.05 \mu \mathrm{m}$ for Carnoy-fixed spores (Summerfelt, 1964, Trans Am Fish Soc 93: 6-10). They also appear within the range of $P$. ovariae spore measurements taken in an extensive geographic survey by Summerfelt and Warner (1970, Am Fish Soc Spec Publ No 5: 142$160): 6.80$ to 8.20 by 4.00 to $4.80 \mu \mathrm{m}$. The spores are, however, somewhat different from those of the other Pleistophora species occurring in ovaries of fish (Table I), as well as another microsporidan, Glugea hertwigi, which also infects fish ovaries; it has a pyriform spore, but it measures 4.6 to 5.4 by $2.3 \mu \mathrm{m}$ (Kudo, 1924, Ill Biol Monogr 9: 268 pp.). G. hertwigi and $P$. ovariae are the only two microsporidans infecting fish ovaries which have been described in the United States.

Histological examination of serial sections of the fathead minnow ovary failed to reveal a typical sporont, but spore masses were very similar to those of $P$. ovariae in golden shiners. Spores either completely filled individual ova or appeared in a dense spore mass or stroma, causing atresia of the ovary. Thus, spore morphology and ovary pathology identify the microsporidan parasite from the fathead minnow ovary as $P$. ovariae, previously observed only in the golden shiner.

Histological examination of a sample of 15 female fathead minnows from another source (Ozark Fisheries, Missouri) did not reveal $P$. ovariae. The incidence of $P$. ovariae in fathead minnows thus appears to be low and should not be of concern to producers of this species. Since the life span of fathead minnows is only 2 or 3 years, producers generally utilize 
1- and 2-year-old brood stock. Producers of golden shiners are similarly limited to these age groups for a different reason-that of controlling the incidence of $P$. ovariae in their stock. Although $P$. ovariae evidently has the potential to infect fathead minnows as well as golden shiners, it may never be a serious problem in this species because of the short life cycle of the fathead minnow.
Mary L. Nagel, Oklahoma Cooperative Fishery Research Unit,* Oklahoma State University, Stillwater, Oklahoma 74074; and Glenn L. Hoffman, Fish Farming Experimental Station, U.S. Fish and Wildlife Service, P.O. Box 860, Stuttgart, Arkansas 72160. *The Oklahoma Cooperative Fishery Research Unit is jointly sponsored by the Oklahoma Department of Wildlife Conservation, Oklahoma State University Environmental Institute, and the U.S. Fish and Wildlife Service. 